\title{
Online Learning of Foreign Language Program in the Intensive Learning Class at the IAIN Padangsidimpuan Language Development Center
}

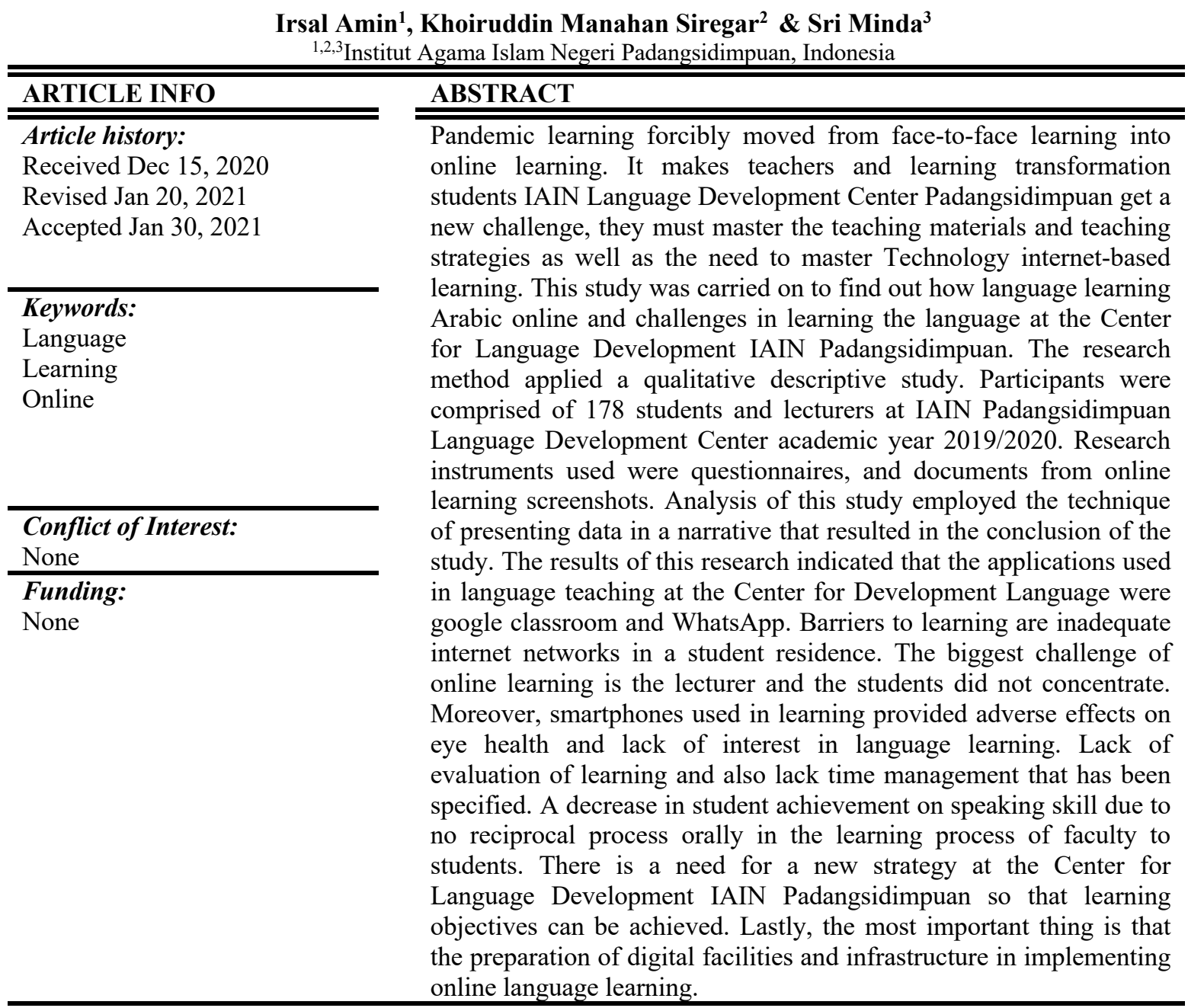

Corresponding Author: Irsal Amin, Lecturer at Institut Agama Islam Negeri Padangsidimpuan, North Sumatera-Indonesia. E-mail: irsalamin@,iain-padangsidimpuan.ac.id

\begin{tabular}{lll}
\hline CC (C) & $\begin{array}{l}\text { C Irsal Amin, Khoiruddin Manahan Siregar, Sri Minda } \\
\text { This is an open access article under the CC BY-SA 4.0 international license. }\end{array}$ \\
\hline
\end{tabular}

\section{Introduction}

Institutions during the Pandemic covid -19 situation becomes like big buildings are uninhabited. Educational theory must have been changed due to the course of concentration, study, and direction of development. So far, most educational theories have focused more on studying and developing face-to-face learning from various aspects. The media used in learning still uses more direct media because language requires more practice than theory. Studies in the form of education and learning theories such as face-to-face classrooms are now unattractive with the current situation.

All learning activities moved from school to house. The teacher teaches students through virtual classes which is a new world for some teachers and students. The shock of congregation occurred in the world of education which resulted in the unpreparedness of schools and the communities in dealing with it, which 
eventually created unresolved turmoil. A lot of data and field facts are real and clear before the eyes show that there is the unpreparedness of the world of education, and society transforming from direct learning to online-based learning or virtual classes. As stated by Adiwijaya Rector Telkom University, 7.5 million students and nearly 45 million elementary and middle school students were forced to learn from home (Anon, 2020).

The learning transformations that occur are forced to create new noise on aspects of education as a whole, starting from the unpreparedness of human resources, digital infrastructure, and the implementation of learning. The presence of this pandemic in our midst is panic as a result of not being prepared to face it. The transformation of educational methods in all aspects becomes a new difficulty in the world of education. As thus, educational methods must quickly make adjustments to the use of information and communication technology in addition to the understanding of many students and some have not mastered the use of this technology so that learning is still not optimal (Anon nd). On the other hand, distance learning in the pandemic period using online (in the network) has a positive impact, namely making education methods more varied, creative, and more active because students and educators have unlimited learning resources (Bhirawa 2020). Even the most important standard component in the world of education is the ability to present remote learning tools based on the internet (Almarabeh et al. 2014).

Regarding the infrastructure side, the Federation of Indonesian Teachers' Unions (FSGI) is not ready for schools to implement online, FSGI conducted a random survey of 245 municipalities in Indonesia that of all respondents said 53.4 percent said the facilities did not guarantee, especially if they were still involved in doing it confectionery (Kamil 2020a). on the one hand, learning that is separated from this distance is understandable if learning aims at cognitive abilities such as understanding, theory, and increased intelligence. However, it becomes a problem if learning aims at skills or abilities that must be evaluated directly, such as skills, attitudes, and language skills.

We need to understand that learning in terms of learning objectives or teaching materials will differ from one another. Exactly learning emphasizes the ability to measure. learning more to study social science and developing a theory of intelligence or analysis, learning techniques, and language becomes a problem in evaluating the achievement of the learning. In evaluating language learning as a way to find out students' abilities in mastery through non-tests, namely having to go through observation sheets such as writing, speaking, and listening skills (Supriyadi 2013: 3).

Language learning, in general, is carried out to master linguistic skills, wherein learning there is linguistic potential, namely the competence of listening, speaking, reading and understanding, and writing (Loren 2017: 3). Language should forward the practice and familiarity with the guidance of a professor or teacher in question so that the quality of their teaching and direction run following the purpose of learning. Of competence is raised all sorts of problems in implementing the foreign language.

The Language development center is an Institution unit within the IAIN Padangsidimpuan as an organizer of Arabic language learning. The Arabic learning program is carried out for five working days each week so that in one semester there are around 120 meetings. Students at the Language Development Center are first and second-semester students who are equalized for one full year on the IAIN Padangsidimpuan campus. The Arabic language learning program is very important and is a superior program so that it becomes one of the business core that is always the topic of discussion for out-of-campus promotions.

Arabic learning at the Language development center focuses on two Arabic languages, namely Arabic and English. For the English language learning program in developing learning methods and techniques in collaboration with the Indonesian Australian Language Foundation (IALF) Bali. Before carrying out learning in class, all English lecturers and teachers are required to follow a one-month quarantine to learn how to teach English. Arabic learning has also carried out various kinds of development of lecturers' abilities in teaching language to students, such as collaborating with the Indonesia ic Center (IAC) training for the Mustaqilli language learning method, and even in 2018, it has collaborated with UIN Sunan Ampel Surabaya to carry out learning and tests. WEB-based language with the Standard Modren ic Language program.

\section{Literature Review}

Learning is the biggest aspect of education, even the educational process is dominated by learning because learning is a reciprocal process between students and teachers/lecturers and students or vice versa. In using the terms learning and education, there are many views among educational experts in defining learning along with the development of time and period and the conditions of learning itself. 
We can take the word learning based on language terminology from Arabic, for example, the word education is taken from the word Tarbiyah where the root word is robba, ta ' dib which is taken from the word addaba, and ta lim from the word allama (Muhmidayeli 2011: 11). In Indonesian, the word education is taken from the word teach or teach, namely instructions given to people so that they are known (KBBI, 2008: 230). Various words describe education or learning even though the orientation is the same, namely to explain learning itself, there is a process of directing students from all aspects to get changes in both cognitive and behavioral ways. BF Skinner even argues that learning is a progressive behavior, where when people learn the response will get better or vice versa (Syaiful 2010: 61).

In the definition of learning, there is the word directing students to get changes both cognitive and behavioral, so this shows that there are many ways that teachers can do in the learning process. The learning process that we understand and see and even feel around us is the interaction between teacher and student at the same place or on a predetermined schedule, in that process face-to-face verbal communication occurs between the teacher and students who are placed in a place or what we know as a class.

An understanding of learning above refers to the notion of learning in conventional form or understanding of traditional learning where the interaction of learning that happens in one place and scheduled certainly who has been assigned by an agency that has the authority to regulate the learning. A model like this is a learning model that has been used around for a long time and is even the result of the thinking of educational thinkers or learning from time to time before the time of technology. This conception of education in the learning process is called intelligence software, the learning model is developed by thinkers - thinkers like Ivan Pavlov education, B. F. Skinner, A Ausubel, Robert Gagne, Benjamin. S. Bloom, where they find thinking patterns in conditioning human learning (Darmawan, 2014: 3).

The form of learning that has been conceptualized from the past is a form of face-to-face interaction learning between the teacher and students. However, the presence of technology in the 20th century in various aspects became a new challenge for educational thinkers and practitioners to create learning concepts that were not based solely on intelligence software, but how to combine intelligence software with hardware intelligence. If both are mated, it will produce a model of learning that follows the natural process of its information and communications technology or are familiar with e-learning. The learning process is carried out to use an electronic or computer system that is capable of supporting the learning process (Micheal, 2013: 27). The Learning took place with the help of electronic and computerized to help achieve the goal of learning that has been designed.

E-learning is learning with a modern concept, or what is often referred to as online learning (in a network) by combining learning principles into communication and information technology. This learning model opens a new paradigm of learning centered on the teacher (teacher-centered) be centered off the learning, and students (student-centered) with the use of technology into the process (MT, Hermawan, and Supuwiningsih 2012: 3). According to Dedi Darmawan (2014), e-learning was first introduced by the University of Illinois at Urbana-Champaign using a computer-assisted instruction system and a computer called PLATO (Arifin and Ekayati 2019: 3). This e-learning learning has been known in Indonesia since 1995, namely the presence of computers and the internet in the commercial form (Etik, Lustyantie, and Emzir 2020: 35). Distance learning is an option in conducting learning in the development of the world of technology to provide convenience and ease in carrying out learning between the teacher and the one being taught.

The implementation of computer-based learning can be categorized into two parts, namely offline learning (computers not connected to the internet) and learning with an online system (computers connected to an internet network). Of the two learning models above, both use a computer which is an e-learning learning system, because e-learning is a phrase composed of e means electronic and learning is learning so both are combined into e-learning, meaning learning is carried out using electronics as learning to use electronic tools, in this case, are computers, multimedia, in-focus and so on (Mahnun nd: 30). In learning activities, all types of media that utilize electronic devices include e-learning, but then the definition transforms along with the development of the times so that the meaning of e-learning is categorized as online-based learning (Munir 2009: 202).

Distance learning is also known as distance learning or the implementation of learning in different places. Let's just say that the teacher is at his house and the students are also at their houses, or the both of them are not tied up by any particular place. Technology today brings a lot of convenience in implementing the learning process. The convenience obtained is unlimited because the process can take place with various models with the aim of convenience. E-learning is learning that is done remotely and is not a good attraction 
because it eliminates face-to-face processes between teachers and students even though it becomes a necessity (Pachler and Daly 2011: 1).

In e-learning, there are many references and ways that can be done using planned learning by implementing it in a large scope that is arranged in one educational institution's house or made independently in the form of a website. E-learning is also carried out independently by teachers and students under the convenience agreement between the two. We find many of these learning models in the literature so that they become a guide for understanding in developing it. In this literature, some theories discuss and explain clearly how to form and how to operate it. This e-learning practice is also very easy to obtain both in the form of the basic website and the basic application.

We can find many patterns of e-learning in the form of a website in educational institutions that are technologically established, such as Higher Education Institutions, Modern Schools. The bias is that this model is developed in the world of higher education in order not only as a way to show the existence of the higher education institution but also to provide easy access wherever lecturers and students are. Likewise, schools that are classified as bona fide are ready financially and human resources. Meanwhile, for the implementation of e-learning learning in the form of application we have encountered many that have been developed by learning developers. Learning application models are likely to develop as quickly as possible, meaning that in the future of campus will have its e-learning application, because with confidence all star-up enthusiasts must have glanced at the needs of the world of Education and certain institutions.

The explanation above is a description of the e-learning learning model currently being conceptualized and developed by educational institutions. The latest features are used as features to design and create. Every campus and school website always has an online learning link as a way of showing that the Educational Institution puts forward the times following existing technological developments and adapting to the circumstances and needs of students.

Development is always an option echoed by every educational institution, technology as one of the parts that are told and used as promotional material to state that the educational institution is modern and advanced. Students usually in choosing educational institutions always look at this one side, namely the word modern learning so that there are separate indicators in making choices. Choosing education for students has many considerations, one of which is the technology side with the hope that after completing education at the institution, they will be able to become people who understand and master technology.

This picture is a form that has been created in the current education environment in the form of writing and speech that we can read and listen to from various sources, but if we look at the reality in the field it becomes something contrary to what it should be, where it is just concepts and ideas of development in the future, but not in implementation. In various seminars, many have been carried out on the use of technology in learning, technology helps the process of distributing teaching materials, although in practice it is still an option.

Using technology in the learning process is not just an idea, and now it has become the main media even though in a very simple form, it only uses common social media applications used in everyday life, such as WhatsApp, Telegram, and goggle classrooms. According to this writer, it is a form of e-learning because the process also meets the criteria for distance learning, namely the Learning Management System (LMS). Learning this model takes place as well as communication in everyday life in the WA or telegram group. Using the google classroom application in learning is also a model that is in-group "wa" or the like, namely the existence of a communication process between the two main components.

The Covid 19 pandemic is like heroin sparking the rapid implementation of distance learning. No campus in Indonesia does not implement distance learning, schools using television. The IAIN Padangasidimpuan campus in the learning process is also carried out by a distance method with a variety of existing application options. Lecturers carry out distance learning as the institute's recommendation is google classroom, but many also use the WA Group because it is easier and more efficient. For example, the IAIN Padangsidimpuan Language Development Unit on average uses the WhatsApp group in the learning process.

Distance learning using social media is included in e-learning? Maybe -this is a question that comes to our minds in these times of limitation today. So, to answer this question we must refer to what media are used, but look more at the role of the internet in the learning process. In Balaji, Al-Mahri, and Matari, it is stated that the role of e-learning is to increase learning creativity because it gives students the potential to communicate with lecturers, colleagues, and to access more subject matter sources (Saifuddin 2018: 103). Online learning is learning that uses the internet with accessibility, connectivity, flexibility, and the ability to generate various types of learning interactions. The use of the internet and multimedia technology can change 
the way of sharing knowledge and can be an alternative to learning that is carried out in traditional classrooms. Online learning is learning that can bring together teachers and those who are taught to carry out learning interactions with the help of the internet. Various social media are used in carrying out online learning or lectures, apart from having many technical conveniences as well as reducing the negative impact of social media which many have recently complained about (Kuntarto 2017: 109).

E-learning is the most idealistic position is a complement to conventional classes face-to-face meaning that it is open to replace its position because in its function that e-learning is in addition to face-to-face meetings and seeing developments and the current situation is the best alternative to implement learning (Khatimi 2006: 80). The complement to face-to-face learning here is to provide more communicative interactions between the teacher and their students and it takes place in a normal state, namely a state or condition of learning without a barrier to doing it in the classroom. In conclusion, distance learning carried out by utilizing social media is included in the e-learning category. On the other hand, learning is carried out in addition to paying attention to the media, it should pay attention to the learning trilogy which includes objectives, processes, and learning evaluation. Then learning is determined based on how the goals and processes are achieved through evaluation.

Learning through the concept of e-learning is an ideal process concerning the development of Covid 19, namely limiting close interactions between teachers and students, students, and other students as an effort to break the chain of distribution. The result of the lack of direct interaction between the two elements in education will result in a lack of attitude transfer process because a teacher is unable to see directly the changes that occur in students so that the role of the teacher in changing the behavior of students becomes ineffective. Imam Al-Gazali (2017) suggests that learning emphasizes moral requirements as the teacher's identity as a mu'allim, meaning that teachers must have a good moral role in teaching and vice versa (Hermawan 2017: 84). And what really needs to be considered in all forms of learning both direct and distance must pay attention to the concept of effective learning, namely the management of learning implementation, communicative processes, student responses, learning activities (Bistari 2018: 13). Effective learning will produce learning that is under the objectives that have been planned, in this case, the objectives of foreign language learning.

\section{Method}

This research is a qualitative descriptive study, namely to describe learning foreign languages online. To obtain research data, researchers distributed questionnaires online to 178 samples consisting of Arabic students and lecturers in the IAIN Padangsidimpuan Language Development Center for the 2019/2020 academic year. Techniques in determining the research sample using random sampling among students and lecturers of Arabic / English. The research instruments were questionnaires, online learning screenshot documents, and Arabic students' final grades. To analyze data, the researchers used a narrative data presentation technique to produce research conclusions.

\section{Results and Discussion}

To find out the reality of learning Arabic online at the IAIN Padangsidimpuan Language Development Center, the researchers gave a questionnaire to 178 informants consisting of lecturers and students at four Faculties, namely the Tarbiyah and Teacher Training Faculty, the Economics Faculty, the Da'wah and Communication Faculty, and the Sharia and Science Faculty Law. The composition of the informants in this study consisted of $15,2 \%$ were lecturers and $84.8 \%$ were students.

From research to know that the application is in use in learning English Arabic online large part to use google classroom and WhatsApp, which from data that get explained $70.2 \%$ of learning conducting in using google classroom and 29.2\% using WhatsApp. The Arabic learning process takes place with the Material Explanation model then discussing or asking and answering questions, although there are still some who do it by just giving assignments. This task-based learning model is few. The online Arabic learning time follows the existing schedule. This implementation is known from the informants' answers and screenshot evidence of learning evidence from each class that is gathered every day.

Online Arabic learning at the language development center goes according to what is expected, where learning is carried out through virtual classes takes place at a set time of 100 minutes each one-time face to face. This is based on the findings of the research questionnaire, namely $82.2 \%$ carrying out learning with a specified order and time. In online learning the obstacle is the inadequate internet network from home and the load on the internet quota, meaning that the stability of the network in most students is in areas with poor signal, namely $54.8 \%$. 
Then in terms of focus and effectiveness of learning, from the data collected that when carrying out learning, students and lecturers do not focus, it means opening many applications when learning takes place and they feel that online learning is not effective in achieving the goals of learning Arabic. Of all the informants said that they wanted and missed learning, as usual, namely direct face-to-face learning even though when carrying out online learning there were many electronic sources.

Learning Arabic online at the IAIN Padangsidimpuan Language Development Center is not effective because the areas of the majority of students do not have a qualified internet network. Then from their admission that this online learning also has a bad influence on health. Apart from the health aspect, this online learning also has its problems, namely the failure to achieve linguistic competence, especially listening and speaking competence.

\section{Conclusion}

Many education experts say that online learning is the reality of future learning. Many public and private campuses in normal times have generally required $60 \%$ face-to-face learning and $40 \%$ online. Learning, in general, is understandable but different from language, especially at IAIN Padangsidimpuan. Online language learning is carried out using the google classroom application and WhatsApp. Online learning in the IAIN Padangsidimpuan environment has not been effective because of the condition of the student's residence that has not been supported by an adequate internet network so that face-to-face learning is something that is missed. And one of the biggest problems is the inadequacy of the goal of language learning, especially in listening and speaking competencies.

\section{References}

Almarabeh, Tamara, Hiba Mohammad, Rana Yousef, and Yousef Kh. Majdalawi. 2014. "The University of Jordan E-Learning Platform: State, Students' Acceptance and Challenges." Journal of Software Engineering and Applications 07 (12): 999-1007. doi: 10.4236 / jsea.2014.712087.

Anon. nd "Metamorphosis of the World of Education in the Covid-19 Pandemic." coil. Retrieved December 16, 2020 (https://kumparan.com/kumparantech/metamorfosis-dunia-pend Pendidikan-di-masapandemi-covid-19-1tK7GRI8RjV).

Anon. nd "Challenges and Constraints of Online Learning." coil. Retrieved December 16, 2020c (https://kumparan.com/selviandriani42/tantang-dan-kendala-pembelajaran-online-1th97TGCm1D).

Arifin, Muhammad, and Rini Ekayati. 2019. Edmodo-Based E-Learning. Deepublish.

Bhirawa, Danu. 2020. "Metamorphosis of the World of Education during the Covid-19 Pandemic." Daily Bhirawa Online. Retrieved December 16, 2020 (https://www.harianbhirawa.co.id/metamorfosisdunia-pend Pendidikan-dalam-masa-pandemi-covid-19/).

Bistari, Bistari. 2018. "Concepts and Indicators of Effective Learning." Journal of Learning and Scientific Studies 1 (2): 13-20.

Darmawan, Dedi. 2014. Development of E-Learning (Theory and Design). Vol. 1. Bandung: Rosdakarya.

Ethics, Ethics, Ninuk Lustyantie, and Emzir Emzir. 2020. "The Effect of Cooperative Learning and Thinking Ability toward Writing Skill of Exposition Paragraph." SALTeL Journal (Southeast Asia Language Teaching and Learning) 3 (2): 22-31. doi: 10.35307 / saltel. v3i2.50.

Hermawan, Asep. 2017. "The Concept of Learning and Learning According to Al-Ghazali." QATHRUNÂ 1 (01): 84-98.

Kamil, Irfan. 2020a. "Federation of Teachers' Union: 55 Percent of Schools Not Ready for New Normal Learning Page All - Kompas.Com." Retrieved December 16, 2020 (https://edukasi.kompas.com/read/2020/06/26/105820171/federasi-serikat-guru-55-persen-sekolahbelum-siap-kenormalan-baru?page=all).

Khatimi, Husnul. 2006. "Knowing E-Learning as A Form of Learning Activities." 10.

Kuntarto, Eko. 2017. "The Effectiveness of Online Learning Models in Indonesian Language Lectures in Higher Education." Indonesian Language Education and Literature 3 (1): 99-110. doi: 10.24235 / ileal. v3i1.1820.

Loren, Fabio Testy Ariance. 2017. "The Use of Learning Media on Listening Skill in Teaching Indonesian To Speakers of Other Language (TISOL)." Lingua Didaktika: Journal of Language and Language Learning 11 (1): 1-12.

SALTeL Vol. 4, No. 1, 2021: 11- 17 
Mahnun, Nunu. nd Implementation of Online Learning Learning Management and Optimization Based Online Islamic University in Menwujudkan World Class University.

Micheal, Allen's. 2013. Michael Allen's Guide to e-Learning. Canada: John \& Sons.

MT, Dr Muhammad Rusli, Dr Dadang Hermawan, and Ni Nyoman Supuwiningsih. 2012. Understanding Elearning: Concept, Technology, and Direction of Development. Publisher Andi.

Muhmidayeli. 2011. Philosophy of Education. Bandung: PT. Refika Aditama.

Munir. 2009. "Curriculum Based on Information and Communication Technology (ICT)."

Pachler, Norbert, and Caroline Daly. 2011. Key Issues in E-Learning: Research and Practice. A\&C Black.

National Department Language Center. 2008. Indonesian Dictionary. Jakarta: KEMENDIKBUD.

Saifuddin, Much. Fuad. 2018. "E-Learning in Student Perceptions." Journal of VARIDIKA 29 (2): 102-9. doi: 10.23917 / varidika. v29i2.5637.

Supriyadi. 2013. Evaluation of Indonesian Language Learning. Gorontalo: UNG Press Gorontalo.

Syaiful, Sagala. 2010. Concept and Its Importance of Learning. Bandung: Alfabeta 